\title{
DAYA SAING EKSPOR CENGKEH INDONESIA DI PASAR GLOBAL
}

\author{
Fadhlan Zuhdi ${ }^{*}$, Khoiru Rizqy Rambe ${ }^{2}$ \\ ${ }^{1}$ Balai Pengkajian Teknologi Pertanian Riau \\ Jl. Kaharuddin Nasution km. 10 No. 341, Pekanbaru \\ ${ }^{2}$ Balai Pengkajian Teknologi Pertanian Kepulauan Riau \\ Jl. Pelabuhan Sungai Jang No. 38, Tanjungpinang \\ *Corresponding author: fadhlanzuhdi21@gmail.com
}

\begin{abstract}
Increasing clove export market share in global markets has promising potential. The aims of this study are to identify the market structure of clove exporting countries and to measure the level of competitiveness and competitive advantage possessed by each exporting country. This study used time series data of Indonesian, Madagascar, Singapore and Comoro clove exports since 2001-2019. The CR ${ }_{4}$ method is used to identify the market structure, Revealed Comparative Advantage (RCA) used to measure the level of export competitiveness comparatively and Export Competitiveness Index (ECI) used to identify the competitive advantage of each exporting country. The results of the study stated that the market structure formed leads to an oligopoly market with Indonesia and Madagascar as market leaders. Meanwhile, the level of export competitiveness and competitive advantage possessed by Indonesia tend to increase. To increase the share of Indonesian clove exports can be done by conducting dissemination to clove farmers about cultivation technology. So, the farmers can produce high quality clove.
\end{abstract}

Keywords: clove, competitiveness, ECI, export, RCA

\begin{abstract}
Abstrak: Peningkatan pangsa pasar ekspor cengkeh di pasar global memiliki potensi yang menjanjikan. Tujuan penelitian ini adalah untuk mengidentifikasi struktur pasar yang terbentuk oleh negara eksportir cengkeh dan untuk mengukur tingkat daya saing serta keunggulan kompetitif yang dimiliki oleh masing-masing negara eksportir. Penelitian ini menggunakan data ekspor cengkeh Indonesia, Madagaskar, Singapura dan Comoro secara time series sejak tahun 2001-2019. Metode $\mathrm{CR}_{4}$ digunakan mengidentifikasi struktur pasar yang terbentuk, Revealed Comparative Advantage (RCA) digunakan untuk mengukur tingkat daya saing ekspor secara komparatif dan Export Competitiveness Index (ECI) digunakan untuk mengindentifikasi keunggulan kompetitif masing-masing negara eksportir. Hasil penelitian menyatakan bahwa struktur pasar yang terbentuk mengarah ke pasar oligopoli dengan Indonesia dan Madagaskar sebagai penguasa pasar. Sementara itu, tingkat daya saing ekspor dan keunggulan kompetitif yang dimiliki oleh Indonesia cenderung mengalami peningkatan. Peningkatan pangsa ekspor cengkeh Indonesia dapat dilakukan dengan melakukan diseminasi kepada petani cengkeh terkait dengan teknologi budidaya sehingga dapat menghasilkan produk cengkeh yang berkualitas.
\end{abstract}

Kata Kunci: cengkeh, daya saing, ECI, ekspor, RCA

\section{PENDAHULUAN}

Sektor perkebunan merupakan subsektor penyumbang PDB tertinggi diantara subsektor pertanian lainnya seperti subsektor tanaman pangan, subsektor peternakan dan subsektor hortikultura. Pada tahun 2019, kontribusi sektor pertanian terhadap PDB Indonesia mencapai $9.41 \%$, dengan $35 \%$ dari kontribusi tersebut disumbang oleh subsektor perkebunan 
(Pusdatin, 2019). Selain menyumbangkan PDB, sektor perkebunan juga berkontribusi dalam perekonomian negara melalui investasi yang bernilai tinggi; berkontribusi dalam menyeimbangkan neraca perdagangan; berkontribusi dalam hal penerimaan negara dari cukai, pajak ekspor dan bea keluar; penyediaan bahan pangan dan bahan baku industri; sumber devisa negara dari kegiatan ekspor dan penyerap tenaga kerja (Direktorat Jenderal Perkebunan, 2020).

Cengkeh merupakan salah satu komoditas perkebunan Indonesia yang telah diekspor ke berbagai negara. Ekspor cengkeh Indonesia mengalami peningkatan sejalan dengan peningkatan produksi yang berhasil dilakukan. Pada tahun 2018, Indonesia berhasil mencatatkan produksi cengkeh sebesar 123.399 ton dan mengekspor cengkeh ke dunia sebesar 20.249 ton pada tahun yang sama (FAOSTAT, 2020; Trademap, 2020). Data tersebut menujukkan bahwa Indonesia telah mengekspor cengkeh mencapai $16.4 \%$ dari total produksinya.

Meskipun persentase ekspor cengkeh Indonesia ke dunia tidaklah besar, namun Indonesia telah menjadi salah satu eksportir terbesar cengkeh di pasar global. Pada tahun 2018, pangsa pasar ekspor cengkeh Indonesia di pasar global mencapai $28.29 \%$ atau setingkat lebih rendah dibandingkan dengan pangsa pasar ekspor cengkeh Madagaskar yang mencapai 29.9\%. Tingginya pangsa pasar ekspor cengkeh Madagaskar dikarenakan sebesar $89.86 \%$ dari produksi cengkeh Madagaskar diekspor ke pasar global dan sisanya dikonsumsi di dalam negeri. Indonesia dan Madagaskar pada tahun yang sama telah menguasai pangsa pasar global sebesar 58.19\% (FAOSTAT, 2020; Trademap, 2020).

Keunggulan dari sisi produksi cengkeh yang dimilki Indonesia seharusnya dapat dimanfaatkan untuk lebih meningkatkan volume ekspor cengkeh Indonesia di pasar global. Peningkatan tersebut diharapkan dapat memberikan kontribusi yang lebih terhadap perekonomian nasional. Tanpa harus mengurangi konsumsi cengkeh di dalam negeri, peningkatan ekspor dapat dilakukan dengan peningkatan produktivitas cengkeh nasional. Pada tahun 2018, sebesar $66.84 \%$ perkebunan cengkah merupakan Perkebunan Rakyat (PR) dan sebesar $33.16 \%$ adalah Perkebunan Besar
Swasta (PBS) dan Perkebunan Besar Negara $(\mathrm{PBN})$. Hal tersebut mencerminkan bahwa sebagian besar perkebunan karet dimiliki oleh rakyat/ perorangan sehingga menyebabkan rendahnya produktivitas cengkeh dikarenakan sebagian besar PR dalam penggunaan teknik budidaya serta pascapanen masih belum menggunakan inovasi teknologi (Direktorat Jenderal Perkebunan, 2020).

Keunggulan komparatif dan keunggulan keunggulan kompetitif dapat ditingkatkan dengan melakukan pengembangan daya saing (Lindung dan Jamil, 2018). Oleh sebab itu, tujuan penelitian ini adalah untuk menganlisis posisi daya saing dan keragaan struktur pasar ekspor cengkeh Indonesia ke pasar global sebagai salah satu komoditas ekspor unggulan Indonesia.

\section{METODE PENELITIAN}

Penelitian ini menggunakan data sekunder time series selama 17 tahun (2002-2019) yang dihimpun dari berbagai sumber yaitu FAO, International Trade Centre dan sumber informasi lainnya seperti dari buku dan pustaka lainnya. Data yang telah dihimpun kemudian dikelompokkan menjadi tiga periode waktu yaitu periode I (2001-2007), periode II (20182014) dan periode III (2015-2019). Objek penelitian ini adalah cengkeh yang memiliki kode HS 0907 di mana subjek penelitian adalah negara eksportir cengkeh terbesar di dunia yaitu Indonesia, Madagaskar, Singapura dan Comoro.

Revealed Comparative Advantage (RCA) digunakan dalam penelitian ini sebagai alat analisis untuk mengukur keunggulan komparatif suatu negara. Metode ini juga mencerminkan pola perdagangan yang didasarkan pada perbedaan antar negara secara relatif (Bojnec dan Ferto, 2014; Nikolić et al., 2011). Menurut Granabetter (2016) dan Kuldilok et al. (2013), indeks RCA mudah dihitung dan banyak digunakan untuk mengukur perubahan keunggulan komparatif berbagai macam sektor dan yang utama adalah sektor pertanian. Pada dasarnya, RCA merupakan salah satu metode pengukuran yang berbentuk dinamis dan mampu digunakan dalam melakukan analisis daya saing. Konsep RCA adalah rasio antara pangsa pasar sebuah produk atau sektor tertentu dari suatu negara di 
dalam pasar global dengan pangsa ekspor negara lainnya terhadap total ekspor dunia (Pramesti et al., 2018; Zuhdi dan Suharno, 2016). Menurut Frija et al. (2017), secara matematis RCA dapat dirumuskan sebagai berikut:

$$
R C A_{i j}=\frac{X_{i j} / \sum_{i} X_{i j}}{\sum_{j} X_{i j} / \sum_{i} \sum_{j} X_{i j}}
$$

Dimana $X i j$ adalah nilai nominal ekspor cengkeh (HS 0907) dari negara j (US\$), $\Sigma i X i j$ adalah nilai nominal ekspor total dari negara $\mathrm{j}$ (US\$), $\Sigma j X i j$ adalah nilai nominal ekspor total cengkeh (HS 0907) dan $\Sigma i \Sigma j X i j$ adalah nilai nominal ekspor total dunia (US\$). (Bano dan Scrimgeour, 2012) menyatakan jika nilai indeks RCA kurang dari satu, maka tidak terdapat keunggulan komparatif suatu komoditas pada negara tertentu. Namun, jika nilai indeks RCA lebih dari satu, maka terdapat keunggulan komparatif suatu komoditas pada negara tertentu.

Penjelasan terhadap posisi daya saing ekspor cengkeh Indonesi di pasar global secara komprehensif dapat dijelaskan dengan menggunakan metode Export Competitiveness Index (ECI). Metode ini menunjukkan perbandingan rasio ekspor suatu negara di suatu pasar untuk komoditas dan periode tertentu dengan rasio ekspor suatu negara di suatu pasar untuk komoditas dan periode sebelumnya. Apabila nilai ECI lebih besar dari satu, maka komditas tersebut menghadapi tren daya saing yang meningkat dan apabila nilai ECI kurang dari satu, makan komodita tersebut menghadapi tren daya saing yang menurun (Ariesha et al., 2019). Menurut Mahmood (2000) dalam (Sinta et al., 2017), secara matematis ECI dapat dihitung menggunakan persamaan berikut:

$$
\text { ECIki }=\frac{\left(X k i / X_{W}\right) t}{\left(X k i / X_{W}\right) t-1}
$$

Di mana $X k i$ merupakan nilai ekspor cengkeh oleh negara i, $X w$ adalah nilai ekspor cengkeh dunia, $X k i, t$ adalah periode berjalan dan $t-1$ adalah periode sebelumnya. Jika nilai ECI lebih besar dari satu, maka komoditas ekspor mengalami kecenderungan keunggulan kompetitif yang meningkat dan apabila nilai ECI kurang dari satu, maka komoditas ekspor mengalami kecenderungan keunggulan kompetitif yang menerun.

Concentration Ratio (CR) digunakan untuk menganalisis tingkat konsentrasi pasar, di mana nilai $\mathrm{CR}$ yang digunakan adalah $\mathrm{CR}_{4}$ dan $\mathrm{CR}_{8}$ yang merupakan output pasar yang dihasilkan oleh 4 atau 8 produsen terbesar dalam suatu industri (Narulita et al., 2014). Nilai CR yang rendah menunjukkan bahwa pasar cenderung terdiri dari banyak produsen dan CR yang tinggi mengindikasikan bahwa pasar didominasi oleh negara-negera produsen terbesar (Hanafi dan Tinaprilla, 2019). Pada penelitian ini, rasio konsentrasi pasar yang digunakan adalah $\mathrm{CR}_{4}$ yaitu empat negara terbesar yang melakukan ekspor cengkeh di pasar global. (Saftiana, 2014) merumuskan $\mathrm{CR}_{4}$ sebagai berikut:

$C R_{4}=S i j 1+S i j 2+S i j 3+S i j 4$

Di mana $C R_{4}$ adalah konsentrasi rasio empat negara eksportir cengkeh terbesar di dunia. Sij1 adalah pangsa pasar ekspor cengkeh Indonesia. Sij2 adalah pangsa pasar ekspor cengkeh Madagaskar, Sij3 adalah pangsa pasar ekspor cengkeh Singapura dan Sij4 adalah pangsa ekspor cengkeh Comoro.

Nilai $\mathrm{CR}_{4}$ berada pada kisaran $0 \%$ hingga $100 \%$ di mana nilai tersebut menggambarkan struktur pasar yang terjadi hingga dapat diklasifikasikan berdasarkan besaran nilai $C R_{4}$ itu sendiri. Berdasarkan Lindung and Jamil (2018), klasifikasi struktur pasar berdasarkan nilai $C R_{n}$ adalah :

Tabel 1. Klasifikasi struktur pasar berdasarkan nilai

\begin{tabular}{lc}
\multicolumn{2}{c}{$C R_{n}$} \\
\hline Struktur Pasar & Nilai $C R_{n}$ \\
\hline Pasar persaingan & Mendekati $\%$ \\
sempurna & \\
Persaingan & $<40 \%$ \\
monopolistik & \\
Oligopoli & $>40 \%$ \\
Monopoli & Mendekati $100 \%$ \\
\hline
\end{tabular}

Sumber : Lindung dan Jamil (2018) 


\section{HASIL DAN PEMBAHASAN}

Ekspor merupakan salah satu kegiatan yang dapat dijadikan sebagai sumber pemasukan negara baik itu melalui devisa ataupun biaya lain seperti pajak ekspor, dan bea keluar. Oleh sebab itu peningkatan ekspor menjadi penting karena perannya yang dapat menyeimbangkan nercaca perdagangan nasional. Setiap negara memiliki keingingan untuk dapat menguasai pasar ekspor baik secara regional maupun global karena dengan semakin tinggi pangsa pasar ekspor yang dimiliki suatu negara maka semakin besar peluang untuk dapat menguasai pasar sehingga pendapatan negara melalui ekspor menjadi ke taraf yang optimal. Pada perdagangan cengkeh dunia, terdapat empat eksportir cengkeh terbesar di dunia yaitu Indonesia, Madagaskar, Singapura dan Comoro. Pada tahun 2019, masing-masing negara memiliki pangsa pasar sebesar $43,24 \%$ untuk Indonesia, 23,88\% untuk Madagaskar, $7,05 \%$ untuk Singapura dan $5,91 \%$ untuk Comoro. Ke empat negara tersebut pada tahun yang sama telah menguasai pangsa pasar dunia sebesar 80,08\%. Indonesia saat ini telah melakukan ekspor cengkeh secara dominan dan berkelanjutan ke 21 negara di dunia seperti
Vietnam, Saudi Arabia, Pakistan, Malaysia, Uni Emirat Arab, Belanda, Jerman, Thailand, Mesir dan Australia (Pratama dan Darwanto, 2019).

Vietnam merupakan importir terbesar dengan rata-rata ekspor sebesar 1.485 ton selama periode 2002-2019. Kemudian, importir terbesar ke dua dan ke tiga adalah Saudi Arabia dan Pakistan dengan rata-rata volume ekspor cengkeh masing-masing 843 ton dan 488 ton. Namun, jika dilihat dari sisi pertumbuhan volume ekspor, Jerman dan Mesir merupakan negara yang memiliki pertumbuhan ekspor terbesar yang masing-masing mencapai $633,36 \%$ dan 284,66\%. Hal tersebut mencerminkan bahwa permintaan cengkeh Indonesia dari negara importir selalu meningkat karena selain Jerman dan Mesir, negara lain juga mencatatkan pertumbuhan volume ekspor cengkeh yang positif.

Jika dilihat dari sisi permintaan dunia, total ekspor cengkeh dunia pada tahun 2019 mencapai 66.207 ton dan di tahun yang sama produksi cengkeh Indonesia mencapai 137.758 ton (Direktorat Jenderal Perkebunan, 2020). Hal tersebut mencerminkan bahwa produksi cengkeh Indonesia telah mampu memenuhi kebutuhan cengkeh di dunia.

Tabel 2. Volume ekspor cengkeh Indonesia ke negara importir (ton)

\begin{tabular}{|c|c|c|c|c|c|c|c|c|c|c|}
\hline Tahun & Vietnam & S.Arabia & Pakistan & Malaysia & UEA & Belanda & Jerman & Thailand & Mesir & Australia \\
\hline 2002 & 334 & 211 & 178 & 589 & 336 & 473 & 78 & 75 & 22 & 18 \\
\hline 2003 & 1.751 & 1.901 & 520 & 259 & 592 & 125 & 69 & 20 & 12 & 14 \\
\hline 2004 & 216 & 390 & 178 & 132 & 339 & 169 & 57 & 15 & 2 & 32 \\
\hline 2005 & 1.103 & 724 & 181 & 137 & 284 & 95 & 20 & 34 & 83 & 48 \\
\hline 2006 & 521 & 759 & 275 & 436 & 416 & 92 & 8 & 31 & 235 & 56 \\
\hline 2007 & 997 & 1.560 & 487 & 448 & 505 & 133 & 25 & 46 & 253 & 94 \\
\hline 2008 & 305 & 561 & 77 & 305 & 398 & 81 & 16 & 44 & 268 & 35 \\
\hline 2009 & 567 & 414 & 219 & 156 & 190 & 143 & 0 & 46 & 59 & 44 \\
\hline 2010 & 876 & 650 & 162 & 138 & 301 & 166 & 40 & 39 & 436 & 51 \\
\hline 2011 & 778 & 197 & 163 & 134 & 34 & 188 & 5 & 23 & 304 & 15 \\
\hline 2012 & 1.246 & 453 & 193 & 297 & 75 & 455 & 45 & 37 & 142 & 17 \\
\hline 2013 & 1.168 & 396 & 237 & 227 & 12 & 480 & 59 & 163 & 314 & 5 \\
\hline 2014 & 1.287 & 466 & 511 & 244 & 69 & 679 & 89 & 57 & 487 & 50 \\
\hline 2015 & 3.224 & 720 & 957 & 250 & 316 & 170 & 275 & 75 & 691 & 75 \\
\hline 2016 & 3.834 & 1.327 & 766 & 165 & 335 & 84 & 131 & 71 & 395 & 80 \\
\hline 2017 & 1.109 & 562 & 596 & 126 & 212 & 294 & 171 & 57 & 730 & 120 \\
\hline 2018 & 5.250 & 1.787 & 1.526 & 255 & 808 & 213 & 159 & 83 & 351 & 61 \\
\hline 2019 & 2.158 & 2.100 & 1.559 & 267 & 1.820 & 348 & 107 & 93 & 476 & 100 \\
\hline $\begin{array}{l}\text { Growth } \\
\text { Rate }(\%)\end{array}$ & 77.80 & 74.48 & 40.71 & 10.71 & 72.15 & 22.08 & 633.36 & 24.26 & 284.66 & 65.49 \\
\hline
\end{tabular}

Sumber : Data Primer Diolah, 2020 


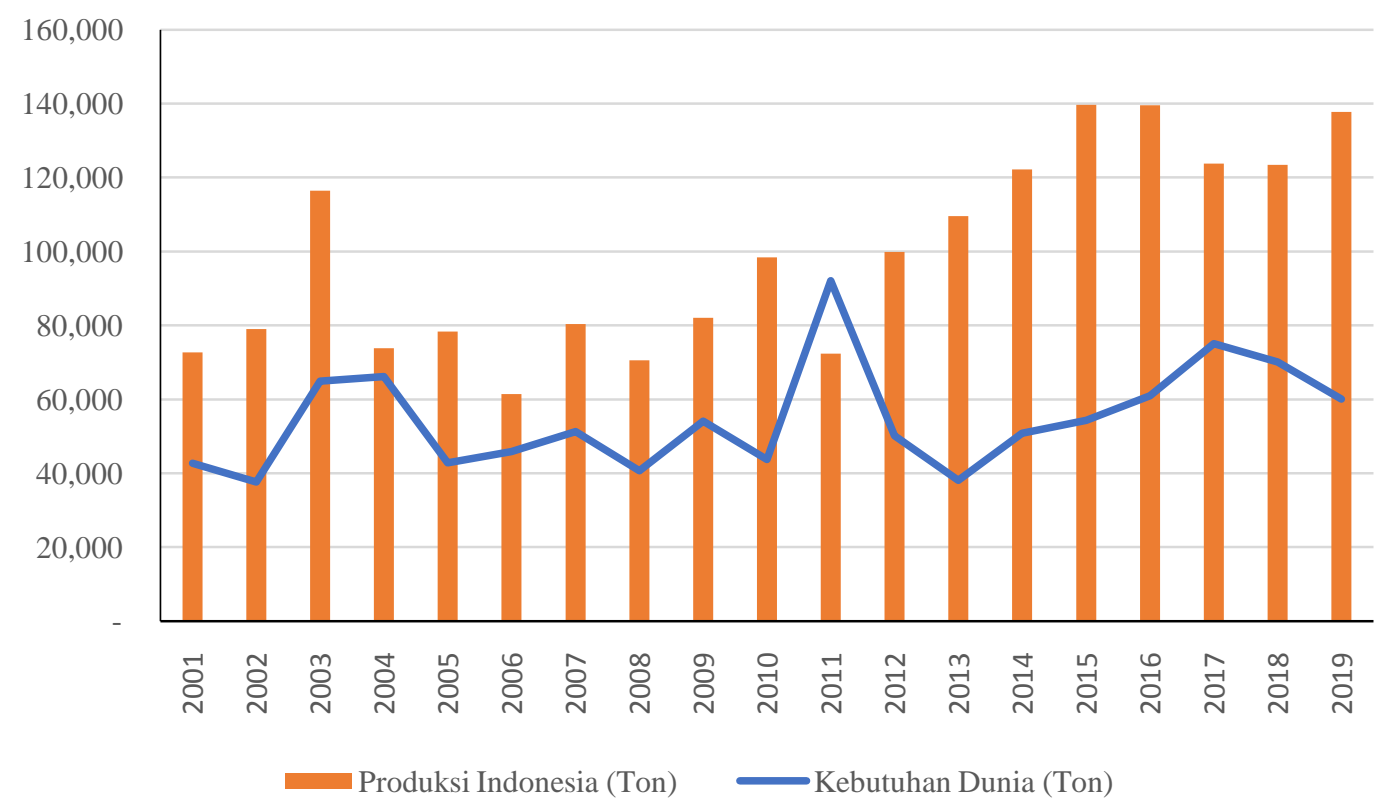

Gambar 1. Total Produksi Cengkeh Indonesia dan Kebutuhan Cengkeh Dunia (Ton) Sumber : FAOSTAT (2020) dan Trademap (2020)

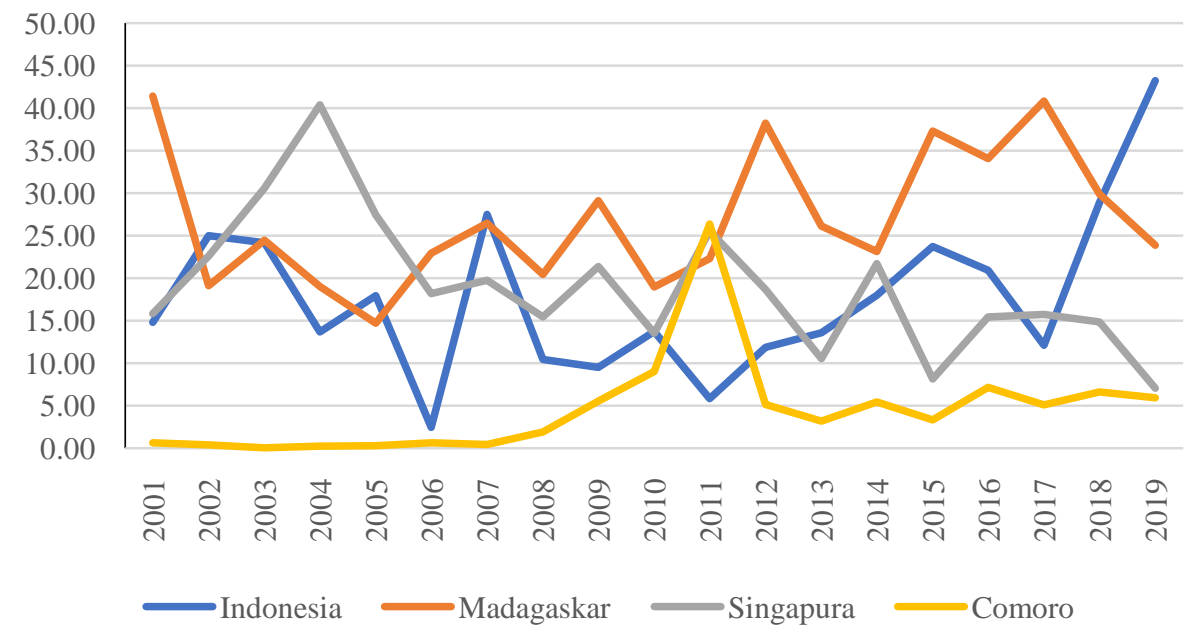

Gambar 2. Pangsa Pasar Ekspor Cengkeh Indonesia, Madagaskar, Singapura dan Comoro di Pasar Global Sumber : FAOSTAT (2020) dan Trademap (2020)

Namun, karena kebutuhan dalam negeri akan cengkeh yang besar membuat ekspor cengkeh Indonesia tidak bisa maksimal.

Trend pangsa pasar ekspor cengkeh dunia untuk ke empat negara eksportir pada periode yang sama juga mengalami fluktuasi, di mana ekspor cengkeh Indonesia ke pasar global cenderung konstan dan menunjukkan peningkatan di beberapa tahun terakhir sedangkan ketiga negara lainnya cenderung menurun. Pangsa pasar ekspor cengkeh Indonesia ke pasar global mengalami peningkatan sejak tahun 2017 sedangkan di tahun yang sama pangsa pasar ekspor cengkeh Madagaskar dan Singapura mengalami penurunan. Hal tersebut menyebabkan Indonesia sebagai negara yang memiliki pangsa pasar ekspor cengkeh terbesar di pasar global saat ini dan mengalahkan pangsa ekspor cengkeh Madagaskar yang sebelumnya cenderung lebih besar. Singapura pada periode waktu yang sama juga mengalami penurunan pangsa ekspor bahkan dapat terlihat bahwa sejak tahun 2004 hingga 2019, pangsa pasar ekspor cengkeh Singapura mengalami penurunan yang sangat besar. 
Zuhdi, F., Rambe, K. R.: Daya Saing Ekspor Cengkeh Indonesia ...

Tabel 3. Hasil Perhitungan $\mathrm{CR}_{4}$ dari ekspor cengkeh Indonesia, Madagaskar, Singapura dan Comoro

\begin{tabular}{lccc}
\hline Tahun & $\mathrm{CR}_{4}$ & Tahun & $\mathrm{CR}_{4}$ \\
\hline 2001 & 72,67 & 2011 & 80,06 \\
2002 & 67,10 & 2012 & 73,94 \\
2003 & 79,24 & 2013 & 53,42 \\
2004 & 73,35 & 2014 & 68,29 \\
2005 & 60,41 & 2015 & 72,48 \\
2006 & 44,25 & 2016 & 77,64 \\
2007 & 74,16 & 2017 & 73,73 \\
2008 & 48,26 & 2018 & 80,28 \\
2009 & 65,55 & 2019 & 80,08 \\
2010 & 55,30 & & \\
\hline
\end{tabular}

Sumber : FAOSTAT (2020) dan Trademap (2020)

Pangsa ekspor cengkeh dunia yang dikuasai oleh ke empat negara eksportir terbesar semakin dipertegas melalui perhitungan $\mathrm{CR}_{4}$ yang dilakukan sejak tahun 2001 hingga 2019. Sejak tahun 2001 hingga tahun 2019 nilai pangsa ekspor cengkeh Indonesia, Madagaskar, Singapura dan Comoro di pasar global sangat besar dengan rata-rata $\mathrm{CR}_{4}$ mencapai 68,43\%. Berdasarkan perhitungan $\mathrm{CR}_{4}$, Indonesia, Madagaskar, Singapura dan Comoro dapat dikategorikan masuk ke dalam pasar oligopoli di mana ke empat negara tersebut memiliki pangsa pasar lebih dari 40\%. Namun, dikarenakan Indonesia dan Madagsakar telah memiliki pangsa pasar yang lebih dari 40\%, maka kedua negara tersebut telah membentuk pasar oligopoli sendiri (Lindung dan Jamil, 2018). Hal ini menyebabkan Singapura dan Comoro tidak lagi diperhitungkan dalam struktur pasar oligopoli yang telah terbentuk oleh Indonesia dan Madagaskar tersebut. Hal tersebut menunjukkan bahwa konsentrasi pasar yang terjadi semakin menyempit sehingga peningkatan daya saing cengkeh secara relatif terjadi di masing-masing negara yang menguasai pasar.

Tingkat daya saing ekspor cengkeh Indonesia, Madagaskar, Singapura dan Comoro dihitung menggunakan metode RCA. Berdasarkan hasil perhitungan, nilai RCA Indonesia cenderung tinggi pada periode I (dengan rata-rata RCA mencapai 17,71 dan mengalami penurunan nilai rata-rata RCA di periode II sebesar 11,87 menjadi 5,84. Namun, pada periode III, rata-rata RCA Indonesia kembali mengalami peningkatan menjadi 19,48. Hal tersebut menunjukan bahwa daya saing ekspor cengkeh Indonesia mengalami peningkatan di periode akhir yang selaras dengan produksi cengkeh Indonesia yang mengalami peningkatan sebesar $2,85 \%$ pada periode akhir perhitungan.

Hasil penelitian (Tupamahu, 2015) menunjukkan bahwa tingkat daya saing ekspor cengkeh Indonesia memang berfluktuatif. Perhitungan nilai RSCA Indonesia pada periode 1980-1993 menghasilkan nilai negatif yang berarti bahwa pada periode tahun tersebut keunggulan komparatif Indonesia lebih rendah dari rata-rata dunia dan tidak memiliki daya saing. Kemudian pada periode tahun-tahun berikutnya, nilai RSCA Indonesia masih tetap bernilai positif meskipun nilainya mengalami peningkatan dan penurunan setiap tahunnya. Hal ini juga sejalan dengan hasil penelitian (Sari dan Widanta, 2018) yang menyatakan bahwa pada tahun 2000-2015, ekspor cengkeh Indonesia memiliki keunggulan komparatif. Namun menurut (Hermawan, 2015), keunggulan komparatif ekspor cengkeh Indonesia pada tahun 2008-2013 telah kalah dibandingkan dengan Singapura.

Madagaskar yang pada periode I penelitian ini menjadi negara dengan pangsa pasar terbesar dan memiliki nilai rata-rata RCA sebesar 2058.25 pada periode yang sama. Kemudian mengalami peningkatan pada periode II menjadi 3192.32. Namun, pada periode III mengalami penurunan menjadi 2617.87. Nilai RCA Madagaskar yang tinggi mencerminkan bahwa cengkeh merupakan komoditas ekspor utama Madagaskar. Hal tersebut tercermin dari data yang dihimpun melalui (Trademap, 2020) yang menyatakan bahwa pada periode penelitian, ekspor cengkeh menyumbang sebesar 5.41 dari total ekspor Madagaskar ke pasar global.

Selaras dengan Madagaskar, Comoro juga memiliki nilai RCA yang tinggi dalam 
Zuhdi, F., Rambe, K. R.: Daya Saing Ekspor Cengkeh Indonesia ...

Tabel 4. Nilai RCA Rata-Rata Indonesia, Thailand dan Malaysia ke Pasar Global

\begin{tabular}{lrrrr}
\hline Uraian & Indonesia & Madagaskar & Singapura & Comoro \\
\hline Periode I & 17,71 & 2058,25 & 13,27 & 8173,01 \\
Periode II & 5,84 & 3192,32 & 11,61 & 86494,14 \\
Periode III & 19,48 & 2617,87 & 7,71 & 20746,59 \\
$\Delta$ Periode I - Periode II (\%) & $-67,02$ & 55,09 & $-12,50$ & 8941,7 \\
$\Delta$ Periode II - Periode III (\%) & 233,56 & $-17,99$ & $-33,59$ & $-76,01$ \\
\hline
\end{tabular}

Sumber : FAOSTAT (2020) dan Trademap (2020)

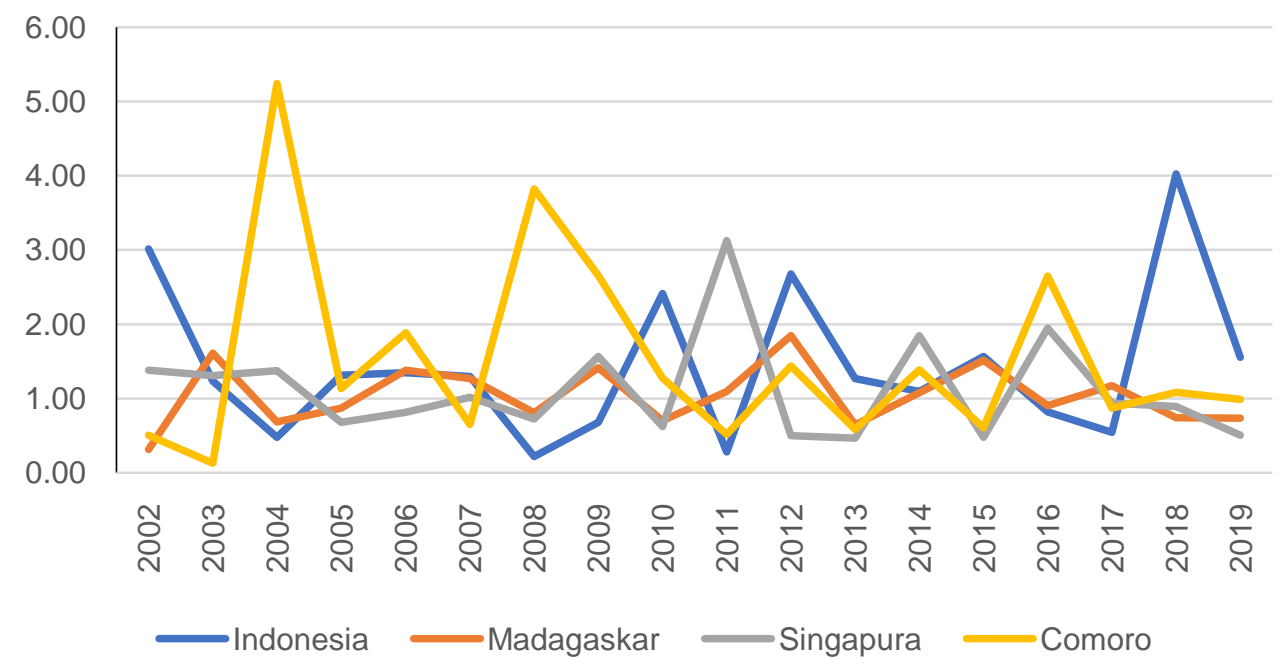

Gambar 3. Indeks ECI Indonesia, Madagaskar, Singapura dan Comoro di Pasar Global Sumber : FAOSTAT (2020) dan Trademap (2020)

periode penelitian. Pada periode I, nilai ratarata RCA Comoro adalah 8173,01 dan meningkat pada periode II menjadi 86494,14. Pada periode III, nilai rata-rata RCA Comoro mengalami penurunan menjadi 20746,59. Nilai RCA Comoro yang tinggi mencerminkan bahwa Comoro menjadikan cengkeh sebagai komoditas utama ekspor dan bahkan menjadi penyumbang devisa terbesar bagi Comoro. Hal tersebut ditunjukkan dari data yang dihimpun melalui (Trademap, 2020) yang menyatakan bahwa ekspor cengkeh rata-rata menyumbang $64,17 \%$ dari total ekspor Comoro ke pasar global.

Pada penelitian ini, keunggulan kompetitif negara eskportir cengkeh di pasar global dapat dilihat dari hasil analisis Export Competitiveness Index (ECI). Secara rata-rata, nilai ECI Indonesia, Madagaskar, Singapura dan Comoro pada periode penelitian memiliki nilai lebih dari satu dengan nilai masingmasing sebesar 1,43, 1,04, 1,12 dan 1,52 sehingga dapat dikategorikan bahwa ekspor cengkeh ke empat negara tersebut ke pasar global memiliki keunggulan kompetitif.

\section{KESIMPULAN}

Berdasarkan hasil penelitian maka dapat disimpulkan bahwa bentuk pasar cengkeh dunia adalah pasar oligopoli dengan lebih dari $40 \%$ pangsa pasar global dikuasai oleh Indonesia dan Madagaskar. Daya saing Indonesia dan Madagaskar mengalami peningkatan sementara daya saing Singapura dan Comoro mengalami penurunan yang terlihat dari rata-rata nilai RCA yang mengalami penurunan di hampir seluruh periode. Hasil perhitungan juga menunjukkan rata-rata indeks ECI bernilai lebih dari satu myang berarti bahwa keunggulan kompetitif masing-masing negara eksportir mengalami kecenderungan yang meningkat. Dengan demikian potensi Indonesia untuk menguasai pasar ekspor cengkeh dunia masih sangat terbuka.

Untuk meningkatkan daya saing ekspor cengkeh Indonesia, dapat dilakukan dengan upaya peningkatan produktivitas cengkeh di dalam negeri. Salah satu cara yang dapat dilakukan yaitu melalui diseminasi teknologi budidaya terhadap para petani cengkeh yang masih melakukan usahatani secara 
konvensional. Diharapkan dengan adanya diseminasi teknologi budidaya tersebut, petani dapat lebih produktif dalam menghasilkan cengkeh yang berkualitas dalam jumlah yang besar sehingga secara agregat total produksi cengkeh Indonesia akan meningkat.

\section{DAFTAR PUSTAKA}

Ariesha, Y., Alamsyah, Z., \& Malik, A. (2019). Analisis komparasi daya saing ekspor lada Indonesia terhadap Vietnam dan Malaysia di Pasar ASEAN. Jurnal Imliah Sosio-Ekonomika Bisnis, 22(1), 80-90. https://doi.org/10.22437/jiseb.v22 i1.8619.

Bano, S., \& Scrimgeour, F. (2012). The export growth and Revealed Comparative Advantage of the New Zealand Kiwifruit Industry. International Business Research, 5(2), 73-82. https://doi.org/10. 5539/ibr.v5n2p73.

Bojnec, S., \& Ferto, I. (2014). Export competitiveness of dairy products on global markets: The case of the European Union Countries. Journal of Dairy Science, 97(10), 6151-6163. https://doi. org/10.3168/jds.2013-7711.

Direktorat Jenderal Perkebunan. (2020). Statistik Perkebunan Indonesia (Cengkeh).

FAOSTAT. (2020). Crops Statistics. Retrieved from Food and Agriculture Organization of the United Nations website: http://www.fao.org/faostat/en/\#data/QC.

Frija, A., Dhehibi, B., Salah, M. Ben, \& AwHassan, A. (2017). Competitive Advantage of GCC Date Palm Sector in the International Market: Market Shares, Revealed Comparative Advantages, and Trade Balance Indexes. International Journal of Marketing Studies, 9(6), 1. https://doi.org/10.5539/ijms.v9n6p1

Granabetter, D. (2016). Revealed Comparative Advantage Index: an Analysis of Export Trade in the Austrian District of Burgenland. Review of Innovation and Competitiveness, 2(2), 97-114.
Hanafi, R. U., \& Tinaprilla, N. (2019). Daya saing komoditas kakao Indonesia Di Perdagangan Internasional. Psikologi Perkembangan, 1-224. https://doi.org/ 10.1017/CBO9781107415324.004.

Hermawan, I. (2015). Daya Saing Rempah Indonesia Di Pasar ASEAN Periode Pra Dan Pasca Krisis Ekonomi Global. Buletin Ilmiah Litbang Perdagangan. https://doi.org/10.30908/bilp.v9i2.6.

Kuldilok, K. S., Dawson, P. J., \& Lingard, J. (2013). The export competitiveness of the tuna industry in Thailand. British Food Journal, 115(3), 328-341. https:// doi.org/10.1108/00070701311314174.

Lindung, L., \& Jamil, A. S. (2018). Posisi daya saing dan tingkat konsentrasi pasar ekspor karet alam Indonesia di pasar global. Jurnal AGRISEP: Kajian Masalah Sosial Ekonomi Pertanian Dan Agribisnis, 17(2), 119-128. https://doi. org/10.31186/jagrisep.17.2.119-128.

Narulita, S., Winandi, R., \& Jahroh, S. (2014). Analisis dayasaing dan strategi pengembangan agribisnis kopi Indonesia. Jurnal Agribisnis Indonesia, 2(1), 63. https://doi.org/10.29244/jai.2014.2.1.6374.

Nikolić, A., Bajramović, S., Ognjenović, D., Lalić, D., \& Uzunović, M. (2011). SEE trade liberalisation - New opportunity for B\&H agrobusiness? British Food Journal, 113(1), 78-95.https://doi.org/ 10.1108/00070701111097358.

Pramesti, F. S., Rahayu, E. S., \& Agustono, A. (2018). Analisis daya saing ubi kayu Indonesia di pasar internasional. SEPA: Jurnal Sosial Ekonomi Pertanian Dan Agribisnis, 14(1), 1. https://doi.org/10. 20961/sepa.v14i1.21034.

Pratama, A. P., \& Darwanto, D. H. (2019). The competitiveness of Indonesian cloves commodity in international market. IOP Conference Series: Earth and Environmental Science, 346(1), 0-9. https://doi.org/10.1088/17551315/346/1/012067.

Pusdatin. (2019). Kontribusi PDB Atas Harga 
Zuhdi, F., Rambe, K. R.: Daya Saing Ekspor Cengkeh Indonesia ...

Berlaku. Retrieved from http://aplikasi2.pertanian.go.id/pdb/rekap pdbkontri.php.

Saftiana, Y. (2014). Analisis hubungan rasio konsentrasi, intensitas iklan, dan profitabilitas industri kosmetik di Indonesia. Jurnal Manajemen Dan Bisnis Sriwijaya, 12(4), 243-258. https://doi.org/10.29259/jmbs.v12i4.317 9.

Sari, K. I. N., \& Widanta, A. A. B. P. (2018). Analisis keunggulan komparatif produk cengkeh Indonesia ke Negara ASEAN Tahun 2015. E-Jurnal Ekonomi Pembangunan Universitas Udayana.

Sinta, N. M., Alamsyah, Z., \& Elwamendri. (2017). Analisis daya saing ekspor.
Jurnal Ilmiah Sosio Ekonomika Bisnis, 20(1).

Trademap. (2020). Trade Statistics for International Business Development. Retrieved from International Trade Centre website: https://www.trademap. org.

Tupamahu, Y. M. (2015). Analisis daya saing ekspor cengkeh Indonesia di kawasan ASEAN dan Dunia. Agrikan: Jurnal Agribisnis Perikanan. https://doi.org/ 10.29239/j.agrikan.8.1.27-35.

Zuhdi, F., \& Suharno, S. (2016). Analisis daya saing ekspor kopi Indonesia dan Vietnam di Pasar ASEAN 5. Habitat Journal, 26, 152-162. 